\title{
Nasal Cavity and Ethmoid Sinus Cancer Pathologic TNM Finding v6
}

National Cancer Institute

\section{Source}

National Cancer Institute. Nasal Cavity and Ethmoid Sinus Cancer Pathologic TNM

Finding v6. NCI Thesaurus. Code C65033.

A pathologic finding about one or more characteristics of nasal cavity and ethmoid sinus cancer, following the rules of the TNM AJCC v6 classification system. 